\title{
"Digital marketing access as a source of competitiveness in traditional Vietnamese handicraft villages"
}

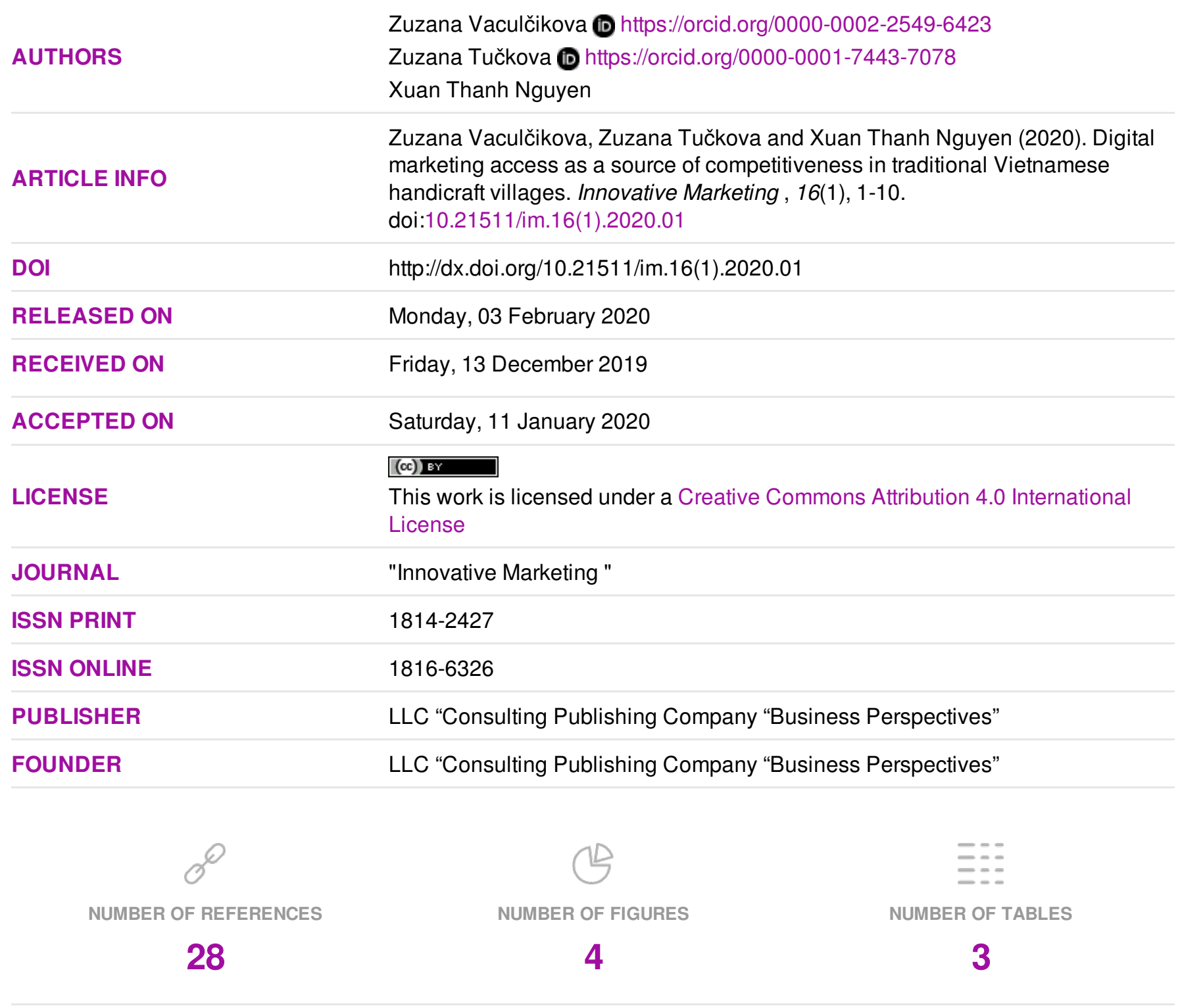

(C) The author(s) 2023. This publication is an open access article. 


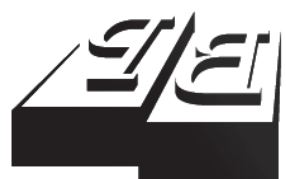

BUSINESS PERSPECTIVES

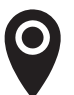

LLC "CPC "Business Perspectives" Hryhorii Skovoroda lane, 10, Sumy, 40022, Ukraine

www.businessperspectives.org

Received on: $13^{\text {th }}$ of December, 2019 Accepted on: $11^{\text {th }}$ of January, 2020

(c) Zuzana Vaculčíková, Zuzana Tučková, Xuan Thanh Nguyen, 2020

Zuzana Vaculčíková, Ing., Ph.D., Department of Enterprise Economics, Faculty of Management and Economics, Tomas Bata University in Zlín, Czech Republic.

Zuzana Tučková, Ing., Ph.D., doc., Department of Logistics, Faculty of Logistics and Crisis Management, Tomas Bata University in Zlín, Czech Republic.

Xuan Thanh Nguyen, Ing.,

Department of Enterprise Economics, Faculty of Management and

Economics, Tomas Bata University in Zlín, Czech Republic.

\section{(ㄷ) (i)}

This is an Open Access article, distributed under the terms of the Creative Commons Attribution 4.0 International license, which permits unrestricted re-use, distribution, and reproduction in any medium, provided the original work is properly cited.
Zuzana Vaculčíková (Czech Republic), Zuzana Tučková (Czech Republic),

Xuan Thanh Nguyen (Czech Republic)

\section{DIGITAL MARKETING ACCESS AS A SOURCE OF COMPETITIVENESS IN TRADITIONAL VIETNAMESE HANDICRAFT VILLAGES}

\begin{abstract}
Traditional handicraft villages have become an inevitable part of Vietnamese culture and play an important socio-economic role within the country's development. However, poor governmental policy and regulatory environment in Vietnam, lack of infrastructure, limited management, marketing skills and knowledge often lead to scarce information to access the market. The aim of the research is to investigate the contemporary status of digital marketing strategies and tools used in handicraft villages in Thua Thien Hue province. It will be complemented by finding out the needs of handicraft businesses about the training course and consultancy on e-marketing. The key quantitative research method is a questionnaire survey of 100 handicraft businesses in 11 villages in Thua Thien Hue province in Vietnam. The results indicated that these businesses do not use digital marketing as the main tool to acquire customers. One of the main reasons can be a fact of not owning sufficient IT technology. However, despite this, businesses realize the need for digital marketing applications and are interested in adopting digital marketing skills and training in order to enhance tourism market access within national and international borders. That is a positive sign for future application of online marketing strategies into business management.
\end{abstract}

\section{Keywords} digital marketing, skills, tourism, traditional handicraft villages, Thua Thien Hue province

\section{JEL Classification $\quad$ M15, M31, M39}

\section{INTRODUCTION}

Improving the performance and increasing the competitiveness of the businesses mean to develop new strategies and marketing innovations (Ungerman, Dedkova, \& Gurinova, 2018). One of the radical tools that changed the world of marketing is the emergence of digital era that has enormously transformed the world of marketing, sales, and consumer behavior. It is much more convenient for a business to place products or services online, attract customers, get feedback from customers, monitor the increasing or decreasing demand, aim marketing to reach concrete target groups online, and, thanks to various managerial software, to monitor current and forecast future revenues. These and many other challenges that digital media brings were not possible several years ago. Being online for the business and for the customers is now a must of most of the companies. Digital media are considered as a successful channel for B2B and B2C communication within any business area. The vast majority of companies already use digital media, social media, and internet for daily communications and successful marketing strategy. The beginning of digital era started with the emergence of first computers and mainly internet that is now considered to be "one of the most important marketplaces for trans- 
actions of goods and services" (Leeflang, Verhoef, Dahlström, \& Freundt, 2014, p. 1). Despite digital media, and especially digital marketing being an important tool, which replaces an old business model with faster, more efficient and convenient communication ensuring better availability of information to potential customer and cost savings, it is still not implemented in some areas. This may result in noncompetitive environment, unfavorable prices, and low production capacity. This is the problem of the traditional handicraft villages in Vietnam. With tourism expansion in Vietnam, traditional handicraft has transformed into souvenir art, and thanks to this transformation, it satisfies the external market even more (Hitchcock, King, \& Parnwell, 2010). Thus, selling handicraft products needs to be supported and promoted in a modern way to reach both national and international customers. One of the effective tools that Blerim (2012) mentions is web marketing that can significantly affect the selling of handicraft products, but this is definitely not the only digital marketing tool that should be used. However, lack of knowledge and skills of local businesses in the field of digital marketing limits its further development. The research aims to analyze the needs of handicraft businesses about the training course and consultancy on e-marketing in 11 villages in Thua Thien Hue province to improve market access. Subobjective of this research is to analyze the current situation of digital marketing adoption in handicraft businesses and the readiness level for digital marketing adoption in handicraft businesses within the literature research. Based on the analyzed results, the authors offer several tools and platforms for initial joining digital marketing for tourism in handicraft businesses. The originality of this paper resides in a unique research topic, as there exist very few current sources dealing with traditional handicraft villages' research in Vietnam and no sources aimed directly at digital marketing in this area. The paper opens with a description of current research state by using scientific literature sources, which is followed by methods used and ends with results and conclusion.

\section{LITERATURE REVIEW}

\subsection{Introduction to traditional handicraft}

Traditional handicraft production is an economically and socially important part of the culture in several countries, including Thailand or Vietnam (Gough \& Rigg, 2012), contributing to rural tourism (Nguyen, 2019) and sustainability of the destinations. It represents the main source of income for many developing countries. Its impact on tourism development is seen in increasing the employment opportunities, providing income generation opportunities, reducing poverty, and preserving traditional culture and heritage. These businesses have huge potential for Vietnamese people and also for exports such as, for example, to the European Union market, which is considered to be a good market for Vietnam's exported handicrafts (Vietnam Trade Information Centre, 2004). Handicraft market includes three major players: (1) artisans and craftworkers as the main producers of goods in villages, where they live, using local material, (2) handicraft exporting companies ensuring spreading of handicraft globally, and (3) Vietnamese government with the role of the promoter (Szydlowski, 2008). In order to increase revenues from handicrafts, all three players should act as one but mainly government should be interested in marketing of handicrafts in order to increase the overall exports (Ahmed, 1980). Handicraft sector has a specific nature and features. Firstly, it needs to maintain originality and local skills by using local materials for the products (Gough \& Rigg, 2012). The production of handicraft products is not unionized, requires low initial capital investment (Ghouse, 2012), high involvement of women and weaker section people, and produces eco-friendly products (Dilip \& Rajeev, 2013). Handicraft production is often presented as an intangible group of skills transformed into tangible in the way of different things such as ceramics, worked wood, metal, furniture, things made from bamboo, sedge and rattan, and others (Kendall, 2014; Vietnam Investment Review, 2005). Its handicraft, non-homogenous nature makes the incomes in the developed countries rise, and the demand for such cultural goods is stimulated (Ghouse, 2012). According to Ministry of Natural Resources and Environment (2008), handicraft villages are divided into six main categories: (1) handicraft fine-art (39\%), (2) food processing $(20 \%)$, (3) textile production, including 
silk production, leather processing, and dyeing (17\%), (4) construction materials and stones production (5\%), (5) waste recycling (4\%), and (6) others such as production of agricultural equipment, including rakes, ropes or shovels (15\%). The biggest share of all handicraft villages includes those businesses producing handicraft fine-art such as bamboo rattan, wood carving, or sleeping mats (Ministry of Natural Resources and Environment, 2008). Other way of handicraft villages mapping is based on the production material such as "(1) rush products, (2) lacquerware, (3) bamboo and rattan products, (4) ceramics, (5) embroidered products, (6) woven textiles, (7) woodcrafts, (8) stone carving, (9) handmade paper, (10) woodblock prints, and (11) metalwork" (Ministry of Agriculture and Rural Development \& Japanese International Cooperation Agency, 2004).

\subsection{Vietnamese handicraft villages}

In Vietnam, handicraft villages have thousands of years-long tradition. The main destinations for Vietnamese handicrafts include Japan, Hong Kong, France, the USA, Australia, the European Union, South Korea, and Taiwan (Vietnam Investment Review, 2005). According to statistics from 2010, Vietnam had around 2,800 handicraft villages (Pearse, 2010), in 2013, it was about 3,000 handicraft villages, out of which 400 were traditional villages (Ministry of Culture, Sports and Tourism, 2013). According to Bui (1996), traditional handicraft villages in Vietnam are defined as the center of handicraft production where there are many households of traditional handicraft with the same handicraft predecessor and production requirements in order to keep the professionalism to cooperate on producing and selling traditional handicraft things in small and medium business market. Ministry of Agriculture and Rural Development (2006) adds that such a place should have at least $30 \%$ of households that are involved and interested in handicraft operations, at least two years' continuation of business and observe the legislation along with implementation of government policies. Traditional handicraft must exist for at least 50 years and must reflect Vietnamese culture and heritage in order to be included in this category. Vietnamese traditional handicraft villages witness several features including (Bui, 1996 in Nguyen, 2019):
"Taking shapes, existing and having a long-standing development in the country.

Assembly producing, forming handicraft villages or streets.

- Having generations of skillful workers and craftsmen.

- Having the stable technique of the Vietnamese nation.

Using the nation's materials.

Being a typical and original product of Vietnam with high value and quality, being an artistic and cultural product and even the nation's cultural heritage with a Vietnamese identity."

For national economics of Vietnam, it is important to note that traditional handicrafts are made of materials available in Vietnam and only $5 \%$ of materials have to be imported (Vietnam Investment Review, 2005).

\subsection{Digital marketing applications in traditional handicraft villages}

The uniqueness of resources used for traditional handicraft in places like Vietnam and its specific managerial potential means using different marketing channels to reach the target audience (Tonkova, 2015). Therefore, using digital marketing can be one of the options that is not used much in this area. Dilip and Rajeev (2013) emphasize the positive impacts of digital marketing in handicraft industry such as (1) e-commerce as the easy way to communicate with customers, (2) cuts costs and saves time, (3) makes organization global without no explicit barriers through internet, (4) greater opportunities to increase sales, (5) more precise target markets, (6) improved marketing research, (7) no entry barrier, and (8) building customer loyalty. Current research on digital marketing deals with strategy, implementation, and practical side also mentioning the skill gaps and challenges facing the industry (Royle \& Laing, 2014, p. 67). The gaps in digital marketing are affected by several elements. Firstly, local handicraft enterprises feel weak in market and marketing information "due to a lack of market study including as- 
pects such as things as customer trends in each country" (Vietnam Investment Review, 2005). It is proven by Ministry of Culture, Sports and Tourism (2013) who states that activities to promote craft tourism villages and local managers operated by Vietnam's Craft Village Association are not reaching significant progress. Secondly, difficulties with digital marketing, such as with web marketing, can also be seen in insufficient cooperation between marketing managers and artisans (Blerim, 2012, p. 2). Although the human labor force in handicraft villages is on a good level regarding the products, manufacture, it witnesses a lack of marketing skills and technology tools to facilitate tourism market access within national borders and abroad (Thi, 2018). The lack of marketing and IT skills is a very common problem and resides from the fact that farmers generally have no qualification in industrial professions, and they learn by themselves, which means that their production is concentrated mainly on traditional working abilities (Anh, 2006). Moreover, handicraft businesses face other marketing problems due to "rapid changes in consumer preferences and tastes, inadequate advertising and publicity, unremunerative pricing and exploitation by middlemen" (Mohapatra, 2011, p. 68). Another problem with handicraft villages is the lack of research on demand and complaints of tourists (Ministry of Culture, Sports and Tourism, 2013), which is closely connected with promotion and developing handicraft village tourism in this area. Although, several initiatives to work on digital marketing skills have been undertaken such as APO Workshop on Trends in the Development of Traditional Craft Villages in the Industry 4.0 Era (APO, 2019), Vietnamese handicraft market still lacks the basic marketing skills and knowledge. Nagori and Saxena (2012) introduce three key principles of improving the marketing of handicraft products, including (1) favoring the activities of rural artisans to reach desirable markets, (2) support of handicraft artisans to meet market needs, and (3) improving the market access, including the relationship with effective promotion.

\section{RESEARCH METHODOLOGY AND DATA}

The current situation of digital marketing adoption and usage of digital tools within handicraft product sector in Vietnam has not been elaborated well in the last years. Literature research proved that the sources regarding digital marketing in Vietnamese handicraft villages are not updated. It is definitely necessary to educate the handicraft businesses about new IT tools and digital marketing techniques as a source for higher exports and better competitiveness. Based on the previous assumptions, this paper aims to investigate the current status of digital marketing strategies and tools used in handicraft villages in Thua Thien Hue province. Based on that, it will be necessary to find out the needs of handicraft businesses about the training course and consultancy on e-marketing to improve market access. This paper draws on intensive research undertaken in 2019 in Thua Thien Hue province. The key quantitative research method is a questionnaire survey of 100 handicraft businesses in 11 villages in Thua Thien Hue province in Vietnam. A minimum of 100 businesses was chosen based on Sudman (1976) who says that typically a minimum of 100 subjects is needed for each category of the major group, and the sample of 30 to 200 elements are sufficient (Kish, 1965). In 2012, there were 11 villages that were listed by the People's Committee of Thua Thien Hue province issued Decision No.29/2012/QĐ-UBND on Regulations of recognizing traditional crafts, craft villages, and traditional craft villages in Thua Thien Hue province. Therefore, these handicraft villages were listed for the sample because the government has paid much attention to recovery of these villages to enhance the culture and heritage of the country, which included Phuong Duc copper casting village, Thuy Thanh conical hat village, My Lam conical hat village, Bao La rattan village, Thuy Lap rattan village, My Xuyen wood carving village, Phuoc Tich pottery village, Pho Trach mat weaving village, Sinh paper painting village, Thanh Tien paper flower village, A Luoi Zèng weaving (Brocade) village (Nguyen, 2019). Data were collected by emailing a questionnaire to chosen businesses; however, due to bad email systems in rural areas, it was necessary to phone businesses and arrange interviews. This helped to receive a higher response rate with better accuracy.

\section{RESULTS}

Handicraft villages in Thua Thien Hue province experience difficulties with accessing the national and international market in which nearly $50 \%$ of 
businesses show that their product can reach the national and international standard. The reasons are either in exporting not suitable products such as conical hats or paper flowers that tourists cannot take home as souvenirs or because of seasonality. Weaving mats, conical hats or rattans were only made by producers when their income is low usually during the seasonality of the farm field. Research results on market access of handicraft businesses in this province say that $56 \%$ access the national market, $18 \%$ international, and $100 \%$ local market.

First of all, it is necessary to ensure that businesses in this province have the infrastructure and necessary equipment to apply digital marketing. In order to find out the readiness level for digital marketing adoption in handicraft businesses, usage of computers, internet, and other digital marketing methods were researched within interviewed group of people. As a result of the study, $75 \%$ of the businesses did not have computers to support their business, only remaining $25 \%$ of the businesses are equipped with computers, this can only be seen in cooperatives, private enterprises and individual business sectors. Further analysis is seen in Table 1.

Table 1. Overview of number of computers at handicraft businesses

\begin{tabular}{c:c:c:c} 
& & \multicolumn{2}{c}{ Source: Author's research. } \\
\hline No. & Details & Frequency & $\%$ \\
\hline 1 & Maximum: 7 computers & 1 & 1 \\
\hdashline 2 & Average: 1.8 computers & 25 & 25 \\
\hdashline 3 & Minimum: 0 computers & 75 & 75 \\
\hline
\end{tabular}

The number of internet users is a key indicator of digital marketing development (Schwarzl \& Grabowska, 2015). As a matter of fact, this was measured in the researched province in order to find out the level of digital marketing and its adoption. As the survey has shown, it witnessed 22 businesses using the internet (approximately $22 \%)$. In Vietnam, it accounts for four methods of internet connection, namely ADSL, 3G or 4G, dial-up and leased line. However, the method which is used the most in those businesses are ADSL (86.4\%) and 3G with 18.2\%. Regarding other methods of digital marketing, respondents use mostly social media marketing that is very popular in businesses and other methods seen in Table 3. However, online advertising is used by $27 \%$ of respondents. Facebook was the most commonly used in their business, estimated at $49 \%$, the second highest was website. Percentage of institutions owning websites was estimated at $18 \%$ and the percentage of institutions willing to build their websites accounted for $27 \%$. As for Instagram and mobile apps, these are still new for those businesses.

Table 2. Methods of digital marketing strategy in handicraft businesses

Source: Author's research.

\begin{tabular}{|c|c|c|c|c|}
\hline No. & Methods & Yes & No & Do not know \\
\hline 1 & Advertisement & 3 & 6 & 2 \\
\hline 2 & Social media marketing & 11 & 0 & 0 \\
\hline 3 & $\begin{array}{l}\text { Search engine } \\
\text { optimization (SEO) }\end{array}$ & 0 & 9 & 2 \\
\hline 4 & Content marketing & 1 & 8 & 2 \\
\hline 5 & Email marketing & 4 & 6 & 1 \\
\hline
\end{tabular}

Source: Author's research.

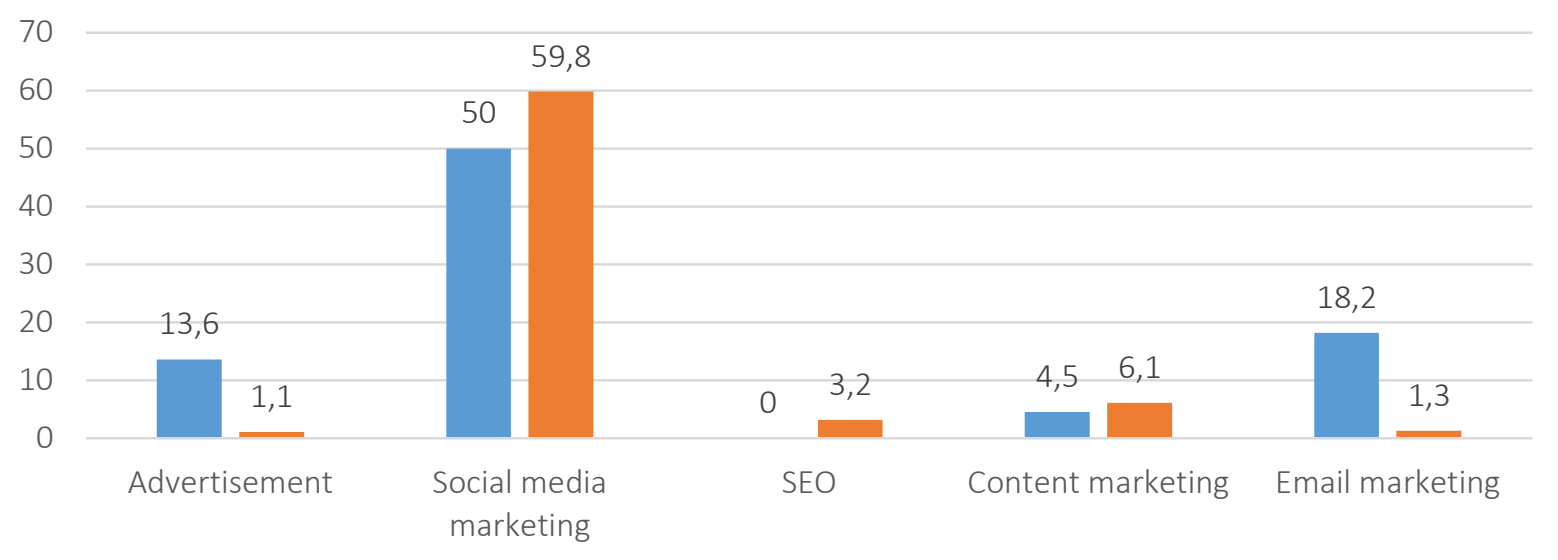

- Thua Thien Hue (\%) घ Vietnam (\%)

Figure 1. The digital marketing strategies applied in handicraft villages 
Table 3. Staffing for digital marketing in handicraft businesses

Source: Author's research.

\begin{tabular}{|c|c|c|c|c|}
\hline \multirow{2}{*}{ No. } & \multicolumn{3}{|c|}{ Thua Thien Hue province } & \multirow{2}{*}{$\begin{array}{c}\text { Vietnam } \\
\%\end{array}$} \\
\hline & Details & $\%$ & Details & \\
\hline 1 & Maximum: 2 staffs & 4.54 & Maximum: 5 staffs & 0.2 \\
\hline 2 & Average: 0.14 staff & - & Average: 0.2 staff & - \\
\hline 3 & Minimum: 0 staff & 59.1 & Minimum: 0 staff & 81.9 \\
\hline
\end{tabular}

In conclusion, Figure 1 indicates that the proportion of handicraft businesses in Thua Thien Hue province using methods for marketing was slightly higher than the average of Vietnam (VCCI-ITB, 2018). As shown in the figure, there was a big difference between handicraft businesses in Thua Thien Hue province and Vietnam regarding the method of advertisement and email marketing at $13.6 \%$ and $18.2 \%$, respectively, while these numbers in Vietnam only accounted for $1.1 \%$ and $1.3 \%$ for each (Nguyen, 2019).

Another problem that comes from the research is suitable education and professionalism in digital marketing of staff that is very limited, as seen from Table 3.

There are three methods of training: self-organize, send staff to training institutions, and provide onsite training. $63.6 \%$ answers in the survey say that they did not join or organize any training activities related to IT or digital marketing for their staffs, the rest of $36.4 \%$ of the respondents went to training. Noticeably, the most popular method of training in those businesses was the on-site training at $22.7 \%$ and $13.7 \%$ of respondents intend to give their employees an opportunity for training (Nguyen, 2019).

Respondents were also asked to evaluate the efficiencies of digital marketing application from their point of view based on three standards, namely (1) expanding the channels for customer communication, (2) promoting the image of the institution and (3) reducing the business expenses. The scale ranged from 1 to 5 as Likert scale from 1 (not efficient at all) to 5 (very efficient). The results are seen in Figure 2.

During the research, it was noticed that $73 \%$ of the respondents reckon that it is very difficult to evaluate their cost efficiency when applying the digital marketing because it is very limited in their businesses leading to the low level of the criteria of reducing cost (average point of 1.5). Respondents still believe that using digital marketing will bring no change in the revenue streams $(55 \%$ of respondents). The rest of respondents believe it can increase. This half-half result may indicate partial unwillingness of digital marketing application. This was confirmed by other research where $50 \%$ of responses reckon the digital marketing was very important for their business. Other opinions on digital marketing are seen in Figure 3.

The analysis clearly shows two poles of the handicraft businesses on digital marketing application. To deal with this, another question about the need of consultancy and training course for digital marketing application was necessary. Only 14\% of respondents went for no for both the needs of consultancy and training courses. On the contrary, most of the people who joined the study wanted to have higher education on digital marketing

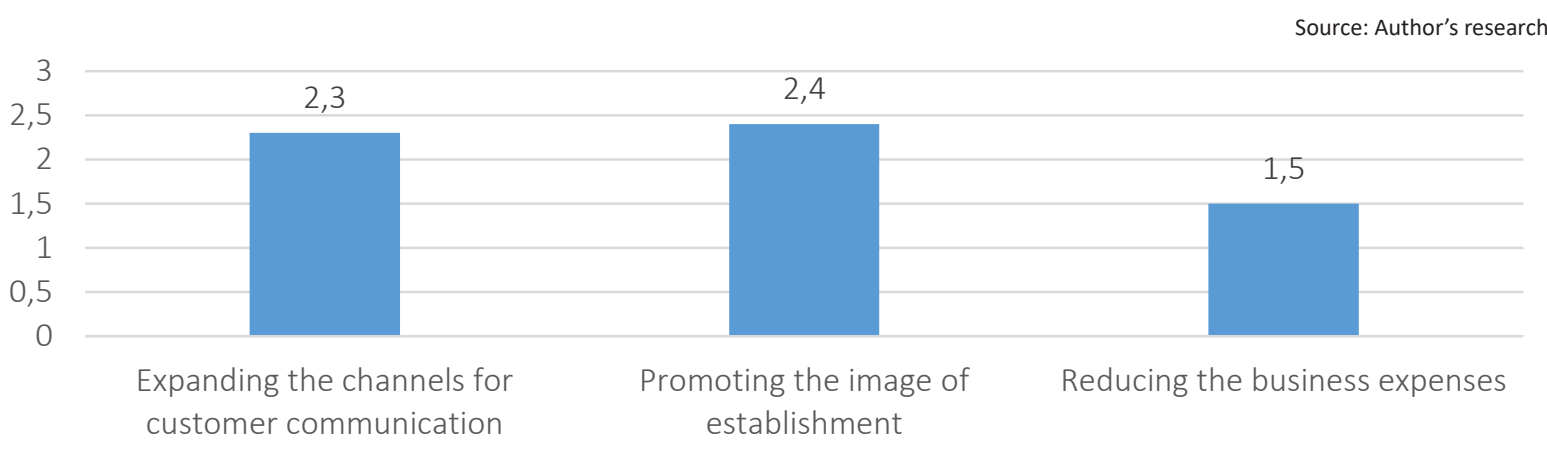

Figure 2. Efficiency of digital marketing application by handicraft businesses 
Source: Author's research.

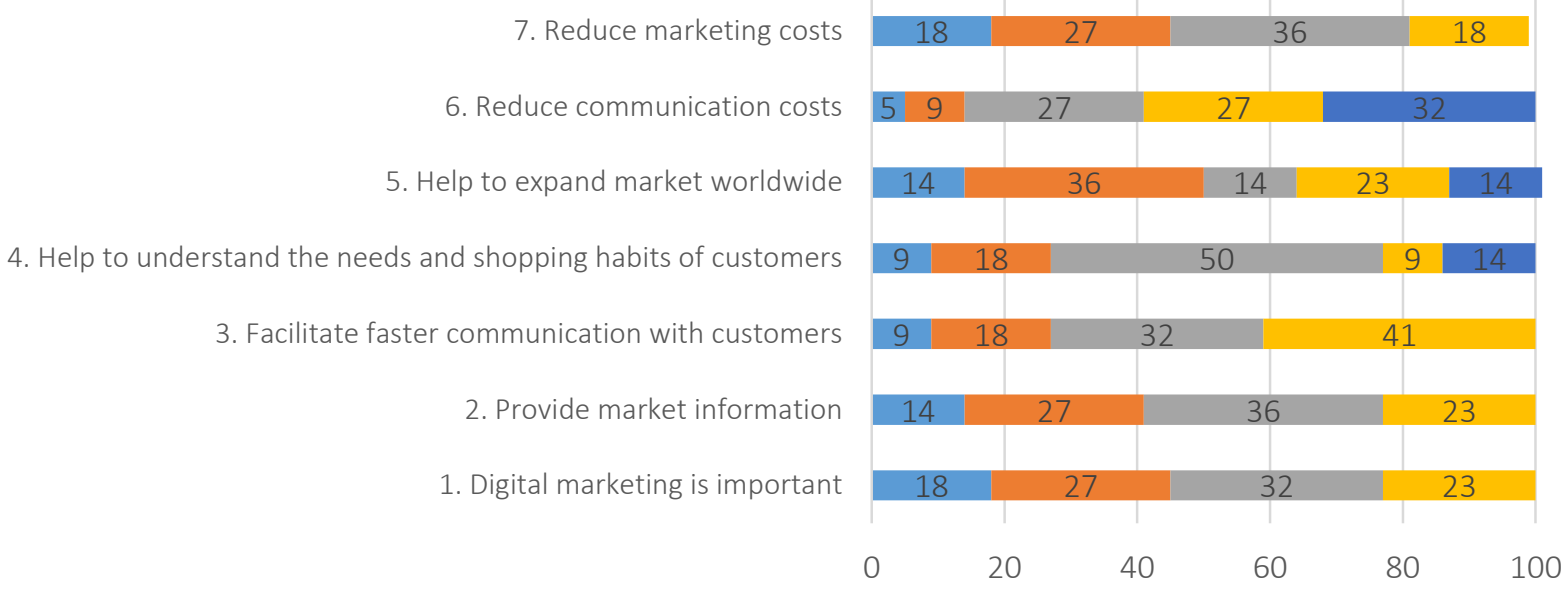

Figure 3. Opinions of institutions about the role of digital marketing application

and its application on rural and domestic market. Especially, the respondents who went for yes take $77 \%$ of the survey, which is the highest trend (Nguyen, 2019). After more detailed analysis of the content of possible digital marketing consultancy and trainings, a graph with the most frequent answers was constructed (see Figure 4).

\section{DISCUSSION}

The importance of digital media in today's marketing strategy is undeniable. Based on the previous results, several suggestions can be made in or- der to enhance digital market access in traditional handicraft businesses in Thua Thien Hue province. A marketing strategy online enables the businesses to measure specifically on how much it costs to have a customer, what are the purchase costs and which channels work best (Nguyen, 2019). There are various platforms where businesses can present their products online. Online marketing strategy of handicraft businesses can be suggested in four main points: (1) content creation, (2) search engine optimization in order to be seen, (3) social media marketing, and (4) email marketing. The best digital marketing strategy is to build content and pictures on the platform that attracts many

1.Instructions on tools for communication with customers (email, Skype,...

2. Introduction to e-marketing and instructions on online marketing

3. Introduction to e-marketing and instructions on email marketing

4. Introduction to e-marketing and instructions on social media marketing

5. Introduction to e-marketing and instructions on marketing via YouTube

6. Instructions on participating in e-marketplaces

7. How to find customers through e-commerce 8. Instructions on online payment

9. Introduction to risk prevention measures in e-commerce 10. Instructions to website building and operating

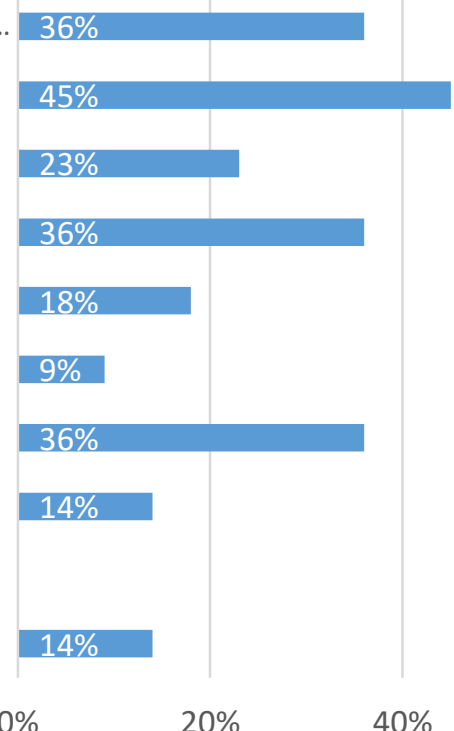

Figure 4. Rate of institutions according to options of training courses 
users such as Facebook, Instagram, websites, and service websites. This is a cost-effective and easy way how to start with digital marketing application within handicraft businesses. Besides, they have to combine the method of advertisement and SEO to push the content up that track more people to come to read the content. The easiest way to promote and start with digital marketing is to use Facebook or Instagram account as it is not difficult and expensive to create a profile. Both are not only built on social platforms, but they are very easily integrated with mobiles, which makes the communication and response time quicker and easier for businesses and customers. However, digital marketing is not really effective without paid content to reach out a wide range of customers as the example of Instagram where sponsored content grows much quicker. Within this research, only 4 businesses were working with websites, which is an alarming fact in today's digital world. Moreover, most companies nowadays have their personal websites so for businesses not using it, it can mean losing customers. If the businesses stay offline, they explicitly give their lost customers to competitors operating at the same market, which is a threat for maintaining the sustainability and competitiveness. Another problem rises with ed- ucation and training of the staff on digital marketing. Even though businesses were interested in training and further education on digital marketing application, they did not need IT technology to support it and use it in their business. Alarming is the fact that $75 \%$ of businesses do not own computers to support their marketing activities and, therefore, the chance for skilled marketing specialists and workforce in this area gets lower. It is supported by $63.6 \%$ of businesses that did not train their employees on IT or digital marketing because the probability of using it in future is taken by businessmen as unnecessary. This may be a result of the fact that more than half of respondents believe digital marketing will not increase their revenues. Therefore, they do not put their effort into education. As a result, get the businessmen and their employees acquainted with marketing processes and techniques will be very difficult, which may generally result in national and global non-competitiveness and insufficient promotion. As handicraft villages have usually limited resources, balancing between digital marketing specialists and specialized labor force is still in consideration of these businesses because of financial situation. Thus, the presence of specialized employees is critical.

\section{CONCLUSION}

Traditional handicraft villages have become an inevitable part of Vietnamese culture and play an important socio-economic role within the country's development in preserving traditional technology, knowledge and heritage. The results of this study confirm and contribute to the literature research aimed at digital marketing in Vietnamese handicraft villages. The purpose of this paper was to investigate the current situation in Thua Thien Hue province regarding using digital marketing in traditional handicraft villages. It builds upon literature research that confirms a lack of digital marketing practice within handicraft businesses. A research gap was seen in non-current data because digital marketing has been developing each year. Possibly, in 2012, it was normal at the time that businesses lacked IT and marketing skills and did not use them for promotion; however, in 2019, it is a must of each prosperous business. Moreover, researches on this topic were mostly aimed at other states, excluding Vietnam, such as India or Taiwan. It is possible to summarize several facts regarding conclusions within research on digital marketing of the businesses in Thua Thuen Hue province:

- the number of internet users (22\%) and owned computers (25\%) demonstrates that the major problem of not using digital marketing is in a lack of IT readiness for digital marketing application. This corresponds to other significant results in this study;

- digital marketing is not considered to be the main activity to acquire the customers;

- the usage of digital marketing tools will not lead to increasing the revenues (55\%); 
- as a result, traditional handicraft businesses do not organize any training on IT and digital marketing (63.6\%);

- although digital marketing is not favored by businesses, they pay much attention to adopting digital marketing, as well as training for enhancing skills and knowledge. They are interested mainly in e-marketing, online marketing, and social media marketing, as well as training on how to find customers by using e-commerce.

Limitations of this research can be seen in a research sample of 100 handicraft business that definitely cannot generalize the whole trend of digital marketing in the province. Although researchers pay attention to digital marketing in handicraft villages, there are still some unexplored sections within the studies. Digital marketing for handicraft villages can be a beneficial topic for the social sustainable development of the country. Therefore, this research may be considered as further primary data for other research with a larger sample to achieve more precise findings.

\section{REFERENCES}

1. Ahmed, N. (1980). Problems and Management of Small Scale and Cottage Industries. New Delhi: Deep and Deep Publication. Retrieved from https://books. google.com.ua/books/about/ Problems_and_Management_of_Small_Scale_a.htm$1 ?$ id $=$ XXYsAAAAMAAJ\&redir esc $=\mathrm{y}$

2. Anh, T. V. (2006). Off-farm business as a poverty reduction actor in Vietnam's rural areas. Institute of Developing Economies, Japan External Trade Organization. Retrieved from https://ir.ide. go.jp/?action=pages_view main\&active_action=repository_ view_main_item_detail\&item_ $\mathrm{id}=26703$ \&item_no $=1$ \&page $\mathrm{id}=39$ \&block_id=158_(accessed on November 5, 2019).

3. APO. (2019). Workshop examines how craft villages continue to evolve. Retrieved from https:// www.apo-tokyo.org/news/aponews/workshop-examines-howcraft-villages-continue-to-evolve/ (accessed on November 26, 2019).

4. Blerim, K. (2012). The marketing of the craft products in Albania, The effects of web Marketing. European Scientific Journal, 8(3). Retrieved from https://eujournal. org/index.php/esj/article/view/52

5. Dilip, K., \& Rajeev, P. V. (2013). A new strategic approach for marketing of handicraft product. International Journal of Applied Services Marketing Perspectives, 2(3). Retrieved from https://www.researchgate.net/ publication/331233388_A_NEW_ STRATEGIC_APPROACH_FOR_ MARKETING_OF_HANDICRAFT_PRODUCTS

6. Ghouse, S. M. (2012). Indian Handicraft Industry: Problems and Strategies. International Journal of Management Research and Reviews, 2. Retrieved from https://www.researchgate.net/ publication/314950589_Indian_Handicraft_Industry_Problems_and_Strategies

7. Gough, K., \& Rigg, J. (2012). Reterritorialising Rural Handicrafts in Thailand and Vietnam: A View from the Margins of the Miracle. Environment and Planning A: Economy and Space, 44(1), 169186. https://doi.org/10.1068/ a44175

8. Hitchcock, M., King, V. T., \& Parnwell, M. (2010). Heritage Tourism in Southeast Asia. Denmark: Nordic Institute of Asian Studies. Retrieved from https://www.niaspress.dk/books/ heritage-tourism-southeast-asia

9. Kish, Leslie. (1965). Survey Sampling. New York: John Wiley and Sons, Inc.

10. Kendall, L. (2014). Intangible traces and material things: the performance of heritage handicraft. Academia Korean a Keimyung Univ, 17(2), 537555. https://doi.org/10.18399/ acta.2014.17.2.001

11. Leeflang, P. S. H., Verhoef, P. C., Dahlström, P., \& Freundt, T. (2014). Challenges and solutions for marketing in a digital era. European Management Journal, 32(1), 1-12. https://doi. org/10.1016/j.emj.2013.12.001

12. Ministry of Agriculture and Rural Development and Japanese International Cooperation Agency. (2004). The study on Artisan Craft Development Plan for Rural Industrialization in the Socialist Republic of Vietnam - Final Report. Vietnam: Hanoi.

13. Ministry of Agriculture and Rural Development. (2006). Guidance for the implementation of Decree No. 66/2006/ND-CP dated 07/7/2006 of the Government on rural development. Hanoi: Vietnam.

14. Ministry of Culture, Sports and Tourism. (2013). Craft village tourism to tap potential. Retrieved from http://vietnamtourism.gov. vn/english/index.php/items/6500 (accessed on October 26, 2019).

15. Ministry of Natural Resources and Environment. (2008). National environmental assessment Environment of Vietnam handicraft villages. Vietnam: Hanoi. 
16. Mohapatra, S. (2011). Problems Associated with Artisans in Making of Handicrafts in Orissa, India. Management Review: An International Journal, 6(1), 56-81. Retrieved from https:// www.researchgate.net/publication/315572539_Problems_associated_with_artisans_in_making of_handicrafts_in_Orissa_India

17. Nagori, N., \& Saxena, K. (2012). Marketing of rural Handicraft products through retail format: A Synthesis Review. Annals of Management Research, 2(1). Retrieved from http://ijmtpublication.com/files/AOMR_2_1_2012/ AOMR_2_1_2012_5.pdf

18. Nguyen, X. T. (2019). Digital Marketing Application to Enhance Tourism Market Access for Traditional Craft Villages in Selected Place (Master Thesis). Zlín: Tomas Bata University in Zlín.

19. Pearse, W. (2010). A look at Vietnam's Plastic Craft Villages. In Our World brought to you by United Nations University. Retrieved from https://ourworld. unu.edu/en/a-look-at-vietnamsplastic-craft-villages (accessed on October 26, 2019).
20. Royle, J., \& Laing, A. (2014). The digital marketing skills gap: Developing a Digital Marketer Model for the communication industries. International Journal of Information Management, 34(2), 65-73. https://doi.org/10.1016/j. ijinfomgt.2013.11.008

21. Sakata, S. (2011). Rural Industrialization and Development of Craft Villages in Vietnam (7th ASAE Conference, Hanoi).

22. Schwarzl, S., \& Grabowska, M. (2015). Online marketing strategies: the future is here. Journal of International Studies, $8(2), 187-196$. https://doi. org/10.14254/2071-8330.2015/8$2 / 16$

23. Sudman, S. (1976). Applied Sampling. New York: Academic Press. Retrieved from https://www. amazon.com/Applied-SamplingQuantitative-studies-relations/ dp/012675750X

24. Szydlowski, R. A. (2008). Expansion of the Vietnamese Handicraft Industry: From Local to Global. Retrieved from https:// etd.ohiolink.edu/\%21etd.send_fi le? accession $=$ ohiou $1218497546 \&$ disposition=inline $($ accessed on November 26, 2019).
25. Tonkova, E. (2015). E-marketing of territories - modern approaches and tools. In A. S. Novoselov \& V.E. Seliverstov Local Production Systems: Analysis and Forecasting of Regional Economic Development. Novosibirsk, Sofia, Lodz, Banska Bystrica, Ternopil. Retrieved from http://dspace. tneu.edu.ua/jspui/bitstream/3 16497/744/1/15.11.17LPS\%20 2015.pdf\#page $=66$ (accessed on October 26, 2019).

26. Ungerman, O., Dedkova, J., \& Gurinova, K. (2018). The impact of marketing innovation on the competitiveness of enterprises in the context of Industry 4.0. Journal of Competitiveness, 10(2), 132-148. https://doi.org/10.7441/ joc.2018.02.09

27. Vietnam Investment Review. (2005). Handicraft Products a Major Sale. Vietnam Investment Review, 7.

28. Vietnam Trade Information Centre. (2004). World Handicraft Market Welcoming Vietnam's Products. Trade News, Hanoi. Retrieved from https://search.proquest.com/ docview/192407411?pqorigsite $=$ summon (accessed on November 26, 2019). 